\title{
RBR: 50 anos. Parabéns e sigamos adiante, sempre
}

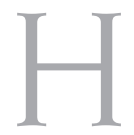

á diversas maneiras de se reconhecer e avaliar a história de uma instituição. Entre elas, a constância e a perenidade de seus feitos. A Revista Brasileira de Reumatologia (RBR) completou 50 anos em setembro de 2007, uma trajetória que poderá ser mais bem conhecida por meio dos editoriais desta edição.

No acompanhamento de tudo o que foi publicado nessas cinco décadas, resumem-se a preocupação e o foco dos interesses científicos, as revisões, o usual e/ou o inusitado no relato de casos, as novas descobertas, as promessas terapêuticas nem sempre realizadas e o próprio, o genuíno, a capacidade intelectual nos trabalhos originais.

A RBR desde sempre contou com o esforço de competentes editores, um autêntico desfile de personalidades da reumatologia brasileira que contribuíram com sua abnegação e seu conhecimento. E quantos fizeram dela a sua estréia como autores em anos de formação, de estágio, de residência? A vitória é a soma desses nomes e vontades. A todos ainda entre nós e à memória dos que já se foram o nosso muito obrigado.

Há muito a ser realizado para torná-la ainda mais atraente aos leitores, e aos autores, é um processo constante de aprimoramento. O sonho de muitos, de vê-la com melhor reconhecimento internacional, será uma realidade; é apenas uma questão de tempo.

O importante agora é comemorarmos este marco. Estamos todos de parabéns, a RBR é uma de nossas bandeiras, representa cada um e todos os nossos associados. Para felicidade nossa, em nome da diretoria desta gestão, cumpre-nos a honrosa tarefa de conduzi-la nesta etapa do trajeto para que permaneça altiva e forte nos próximos cinqüenta anos e adiante, sempre.

Fernando Neubarth

Presidente da Sociedade Brasileira de Reumatologia 